\title{
SINDROM PRAMENSTRUASI PADA REMAJA
}

\section{PRA-MENSTRUAL SYNDROME IN ADOLESCENTS}

\author{
Oleh: \\ Rahmi Susanti ${ }^{1}$, Reny Noviasty², dan Riza Hayati Ifroh ${ }^{3}$ \\ 1 Departemen Biostatistika dan IImu Kependudukan \\ 2 Departemen Gizi Kesehatan Masyarakat \\ 3 Departemen Promosi Kesehatan \\ Fakultas Kesehatan Masyarakat \\ Universitas Mulawarman, Samarinda, Kalimantan Timur, Indonesia \\ Email :rachmi.rachmat@gmail.com
}

\begin{abstract}
Menstruation is an experience for young women. Menstrual experiences can be surprising and full of emotional. Response to menstruation can be a positive response even negative. This research aims to give a picture of the adolescent response that occurs during the pre menstrual period and analyze the factors related to the menstrual period of the first period of menstruation, breakfast habits, and physical and non physical complaints that arise pre menstrual. The population of this study is all young women in RT 23, Bukuan, Samarinda City, The technique used is population study so that the sample taken is young women who have experienced menstrual phases and numbered 35 persons. Based on the univariate test, the syndrome most commonly complained of by adolescents during the pre-menstrual phase is angry ( 29 teenagers), mixed feelings ( 26 teenagers) and as many as 26 teenagers report pain experiences during the period of time (dysmenorrhea). Bivariate test results show there is a habit of breakfast habits with physical complaints (abnormal uterine bleeding and dysmenorrhea) with $p$-value: 0.012 , while in other factors is not indicated a significant relationship. The study provided that out of the whole youth, $82.8 \%$ reported non-physical complaints and $74.2 \%$ experienced physical complaints during the period before and during menstruation.
\end{abstract}

\section{Keywords: Dysmenorrhea, Pre-menstrual, Teens}

\begin{abstract}
ABSTRAK
Menstruasi merupakan suatu pengalaman bagi remaja perempuan. Pengalaman menstruasi dapat mengejutkan dan penuh emosional. Respon terhadap menstruasi dapat berupa respon positif bahkan negatif. Penelitian ini bertujuan untuk memberikan gambaran tentang respon remaja yang terjadi saat pramenstruasi dan menganalisis faktor yang terkait dengan menstruasi yakni usia pertama kali menstruasi, kebiasaan sarapan, dan gangguan somatik dan afektif yang muncul pramenstruasi. Populasi penelitian ini adalah seluruh remaja putri di RT 23 kelurahan BukuanKota Samarinda, Teknik yang digunakan adalah studi populasi sehingga sampel yang diambil merupakan remaja putri yang telah mengalami fase menstruasi dan berjumlah 35 orang. Berdasarkan uji univariat, sindrom yang paling sering dikeluhkan oleh remaja selama fase pramenstruasi adalah suka marah (82,9\%), perasaan campur aduk $(74,3 \%)$ dan sebanyak $74,3 \%$ remaja melaporkan pengalaman nyeri saat periode berlangsung (dysmenorrhea). Hasil uji bivariat menunjukkan ada hubungan kebiasaan sarapan dengan gangguan afektif ( $p$-value: 0,012), sedangkan pada faktor lain tidak ditunjukkan adanya hubungan yang signifikan. Penelitian ini memberikan informasi bahwa dari keseluruhan remaja, 82,8\% melaporkan keluhan non fisik dan $74,2 \%$ mengalami keluhan fisik saat periode sebelum dan saat menstruasi.
\end{abstract}

Kata kunci :Dysmenorrhea, Pramenstruasi, Remaja 


\section{PENDAHULUAN}

Pramenstruasi didefinisikan sebagai kondisi klinis yang mempengaruhi fisik danlebih dari $90 \%$ wanita diseluruh dunia mengalami gejala pramenstruasi selama usia remaja (Zaka and Mahmood, 2012). Tingkat kejadian sindrom pramenstruasi pada 200 responden yang berusia 16-31 tahun di Universitas Calabar, Nigeria dilaporkan sebesar 85,5\% (Antai et al., 2010). Dalam penelitian lain yang dilakukan oleh Takeda et al (2006) melaporkan dari 1152 wanita di Jepang $93,5 \%$ mengalami sindrom pramenstruasi ringan, 5,3\% mengalami sindrom pramenstruasi tingkat sedang hingga berat dan $1,2 \%$ mengalami premenstrual dysphoric disorder (PMDD).

Gejala somatik (fisik) yang termasuk dalam premenstrual dysphoric disorder adalah kelelahan, perut kembung, nyeri payudara, sakitkepala, jerawat dan pembengkakan di ekstremitas. Gejala afektif meliputi lekas marah, ledakan kemarahan, mudah marah, depresi, kebingungan, kecemasan, danpenarikan diri dari lingkungan sosial (Shamnani et al., 2018). Diperkirakan terdapat $85 \%$ perempuan akan mengalami setidaknya satu hingga gejala pramenstruasi dalam kurun waktu dua minggu yaitu 3 hari sebelum masa menstruasi ditambah 2 sampai 4 hari pasca menstruasi (Ahmed and Saeed, 2019).

Berdasarkan kondisi dan gejala yang muncul tersebut, dapat dipastikan remaja akan cenderung mengalami penurunan produktivitas serta rasa tidak nyaman yang dapat mengganggu aktivitasnya (Puspitasari, Elfidasari and Rahayu, 2014). Salah satu faktor yang dapat menjadi pemicu terjadinya sindrom pramenstruasi adalah status gizi remaja (Renata, Widyastuti and Nissa, 2018). Gaya hidup, pola konsumsi dan tingkat konsumsi makanan menjadi faktor rendahnya status gizi remaja (Abeje and Berhanu, 2019). Kelompok remaja putri dewasa ini sangat memperhatikan bentuk tubuh dan penampilan fisik, sehingga mereka mulai memperketat asupan makanan yang dikonsumsi serta mengurangi frekuensi makan salah satunya dengan tidak sarapan di pagi hari(Abrani, Ningtyias and Sulistiyani, 2019).
Adapun kandungangizi yang sangat dibutuhkan oleh remaja putri menjelang masa menstruasi yaitu magnesium, kalsium, vitamin B6, protein sehingga meningkatkan hemoglobin dan asupan gizi tubuh tetap terjaga (Sen et al., 2018).

Studi pendahuluan dilakukan dengan melakukan Teknik wawancara pada sejumlah remaja putri terkait informasi Kesehatan reproduksi. Wawancara digunakan untuk menghimpun informasi pengetahuan remaja tentang pengalaman yang dirasakan saat haid, kepada siapa bertukar informasi terkait haid yang dialami dan pengalaman memperoleh informasi personal hygiene menstruasi. Pada saat wawancara, 5 orang remaja berpartisipasi dan menyatakan bahwa mengalami gejala-gejala afektif seperti suka marah dan stress, kemudian remaja tersebut lebih banyak mencari informasi melalui media online dan jarang membicarakan masalah haid dengan orang tua ataupun guru di sekolah. Selanjutnya 3 dari remaja putri pernah memperoleh informasi terkait personal hygiene menstruasi dari sekolah yakni guru dan program Pendidikan Kesehatan dari layanan Kesehatan masyarakat setempat.

Berdasarkan uraian diatas, maka perlu dilakukan kajian mendalam mengenai fenomena serta faktor-faktor yang berpengaruh terhadap kejadian sindrom pramenstruasi padaremaja putri.

\section{METODE PENELITIAN}

Penelitian ini merupakan survei analitik yang mengidentifikasi fenomena terkait dengan pramenstruasi hingga menganalisis hubungan usia pertama kali haid, kebiasaan sarapan remaja putri, gejala somatik dan afektif. Pendekatan yang digunakan adalah cross sectional dimana variabel diambil dalam satu kondisi waktu tertentu. Penelitian dilakukan di RT 01 kelurahan BukuanKota Samarinda, untuk menjaga privasi maka nama responden ataupun inisial tidak disebutkan dalam penelitian ini.

Waktu pelaksanaan penelitian ini adalah pada bulan September-Oktober. Populasi dari penelitian ini adalah remaja putri yang terdata pada kartu keluarga di RT 01 yakni 35 
orang yang telah mengalami fase menstruasisehingga studi populasi dilakukan dalam teknik ini untuk pengambilan besar sampel.

Pengumpulan data dilakukan dengan bantuan angket berisi pertanyaan yang dibagi menjadi beberapa kategori yakni identitas responden, kebiasaan sarapan, gangguan somatik dan afektif serta identifikasi sumber informasi kesehatan reproduksi remaja dari sekolah. Data yang telah terkumpul disajikan dalam bentuk tabel dan analisis bivariat dilakukan pada variabel tersebut dengan uji koefisiensi kontingensiuntuk mengetahui hubungan antar tiap variabel yang berskala nominal. Pembacaan nilai signifikansi dilakukan dengan uji fisher eksak karena terdapat nilai $=0$ pada beberapa sel tabel. Korelasi spearman juga digunakan untuk analisis hubungan pada variabel dengan skala ordinal.

\section{HASIL PENELITIAN DAN PEMBAHASAN HASIL PENELITIAN}

Tabel 1. Karakteristik responden penelitian

\begin{tabular}{ll}
\hline Karakteristik & Jumlah $(\%)$ \\
\hline Usia pertama kali haid & \\
$11-14$ tahun & $34(97,1)$ \\
$\geq 15$ tahun & $1(2,9)$ \\
\hline Jumlah hari haid perbulan & \\
$\begin{array}{l}3-7 \text { hari } \\
>7 \text { hari }\end{array}$ & $29(82,9)$ \\
\hline Kebiasaan Sarapan & $(17,1)$ \\
ya & $24(68,6)$ \\
kadang-kadang & $11(31,4)$ \\
\hline Gangguan somatic & \\
abnormal uterine bleeding & $9(25,7)$ \\
dysmenorrhea & \\
& $26(74,3)$ \\
\hline Gangguan afektif & \\
suka marah & $29(82,9)$ \\
suka bingung & $8(22,9)$ \\
perasaan campur aduk & $26(74,3)$ \\
suka menangis & $9(25,7)$ \\
depresi & $10(28,6)$ \\
susah konsentrasi & $17(48,6)$ \\
\hline Keberadaan WC khusus & \\
perempuan & \\
Tidak & $2(5,7)$ \\
\hline
\end{tabular}

\begin{tabular}{|c|c|}
\hline Karakteristik & Jumlah (\%) \\
\hline $\mathrm{Ya}$ & $33(94,3)$ \\
\hline \multicolumn{2}{|l|}{$\begin{array}{l}\text { Ketersediaan air dan sabun } \\
\text { di WC khusus perempuan }\end{array}$} \\
\hline Tidak & $4(11,4)$ \\
\hline $\mathrm{Ya}$ & $31(88,6)$ \\
\hline \multicolumn{2}{|l|}{ Ketersediaan pembuangan } \\
\hline \multicolumn{2}{|l|}{$\begin{array}{l}\text { khusus untuk pembalut } \\
\text { bekas }\end{array}$} \\
\hline Tidak & $13(37,1)$ \\
\hline Ya & $22(62,9)$ \\
\hline \multicolumn{2}{|l|}{$\begin{array}{l}\text { Ruangan penyedia } \\
\text { pembalut gratis di sekolah }\end{array}$} \\
\hline Tidak & $22(62,9)$ \\
\hline Ya & $13(37,1)$ \\
\hline $\begin{array}{l}\text { Informasi } \quad \text { kesehatan } \\
\text { reproduksi }\end{array}$ & \\
\hline informasi dari sekolah & $18(51,4)$ \\
\hline $\begin{array}{l}\text { tersedianya media visual } \\
\text { tentang menstruasi }\end{array}$ & $8(22,9)$ \\
\hline tidak mendapat informasi & $9(25,7)$ \\
\hline
\end{tabular}

Berdasarkan informasi dari 35 remaja diperoleh data bahwa $97,1 \%$ mengalami usia pertama kali haid pada rentang 11-14 tahun, usia ini merupakan usia normal. Lama haid yang dialami responden $82,9 \%$ berkisar 3-7 hari yang merupakan siklus normal pada umumnya. sebanyak $68,6 \%$ remaja memberikan respon memiliki kebiasaan sarapan, $74,3 \%$ menyatakan mengalami dysmenorrhea selama periode haid sedangkan yang lainnya menyatakan mengalami abnormal uterine bleeding.

Pada penelitian ini, dikumpulkan juga informasi terkait prasarana seperti WC khusus perempuan, air dan sabun di fasilitas WC khusus perempuan, pembuangan khusus pembalut dan ruangan penyedia pembalut gratis. 94,3\% responden menyatakan terdapat WC khusus perempuan di sekolah mereka, 88,6\% menyebutkan bahwa terdapat air dan sabun di WC tersebut. Kemudian 62,9\% menyatakan bahwa tersedianya pembuangan khusus untuk pembalut bekas dan 62,9\% memberikan informasi bahwa tidak adanya ruangan penyedia pembalut gratis disekolah.

Pada deskripsi keluhan afektif, setiap responden melaporkan mengalami lebih dari 1 
keluhan. Gangguan yang paling dominan adalah $82,9 \%$ mengalami gangguan afektif yakni suka marah, $74,3 \%$ mengalami perasaan campur aduk, $48,6 \%$ lainnya mengalami susah konsentrasi di sekolah ataupun di rumah serta $28,6 \%$ menyatakan mengalami depresi.
Diperoleh juga data bahwa $51,4 \%$ remaja siswi memperoleh informasi dari sekolah terkait kesehatan reproduksi dan22,9\% menerima dalam bentuk media visual.Walaupun demikian masih terdapat $25,7 \%$ responden menyatakan tidak memperoleh informasi terkait Kesehatan

reproduksi

Tabel 2. Hasil uji bivariat usia pertama kali haid dengan keluhan somatik

\begin{tabular}{|c|c|c|c|c|c|}
\hline Usia pertama kali & Keluha & matic & Frekuensi & $\%$ & $p$-value \\
\hline haid & $\begin{array}{c}\text { Tidak } \\
\text { mengalami }\end{array}$ & Mengalami & & & \\
\hline $11-14$ tahun & 5 & 29 & 34 & 97,14 & 0,742 \\
\hline Lebih dari 15 tahun & 0 & 1 & 1 & 2,8 & \\
\hline Total & 5 & 30 & 35 & 100 & \\
\hline $\begin{array}{l}29 \text { remaja yan } \\
\text { somatic berada pada } \\
\text { tahun dan satu oran } \\
\text { somatic yang berusia } \\
\text { bivariat yang dilakuk } \\
\text { kontingensi dengan m }\end{array}$ & $\begin{array}{l}\text { mengalami } \\
\text { tang usia } 1 \\
\text { mengalami } \\
\text { atas } 15 \text { tah } \\
\text { adalah } \mathrm{k} \\
\text { baca hasil }\end{array}$ & & $\begin{array}{l}\text { gandung nil } \\
\text { sar } 0,742 \text {. } \\
\text { va tidak ada } \\
\text { dengan ke } \\
\text { di sekolah } \\
\text { arinda. }\end{array}$ & $\begin{array}{l}\text { (nol). di } \\
\text { an demi } \\
\text { ungan us } \\
\text { somati } \\
\text { engah sv }\end{array}$ & $\begin{array}{l}\text { en } p \text {-value } \\
\text { dinyatakan } \\
\text { rtama kali } \\
\text { da remaja } \\
X \text { di Kota }\end{array}$ \\
\hline
\end{tabular}
dari uji eksak dari fisherkarena salah satu sel

Tabel 3. Hasil uji bivariat usia pertama kali haid dengan keluhan afektif

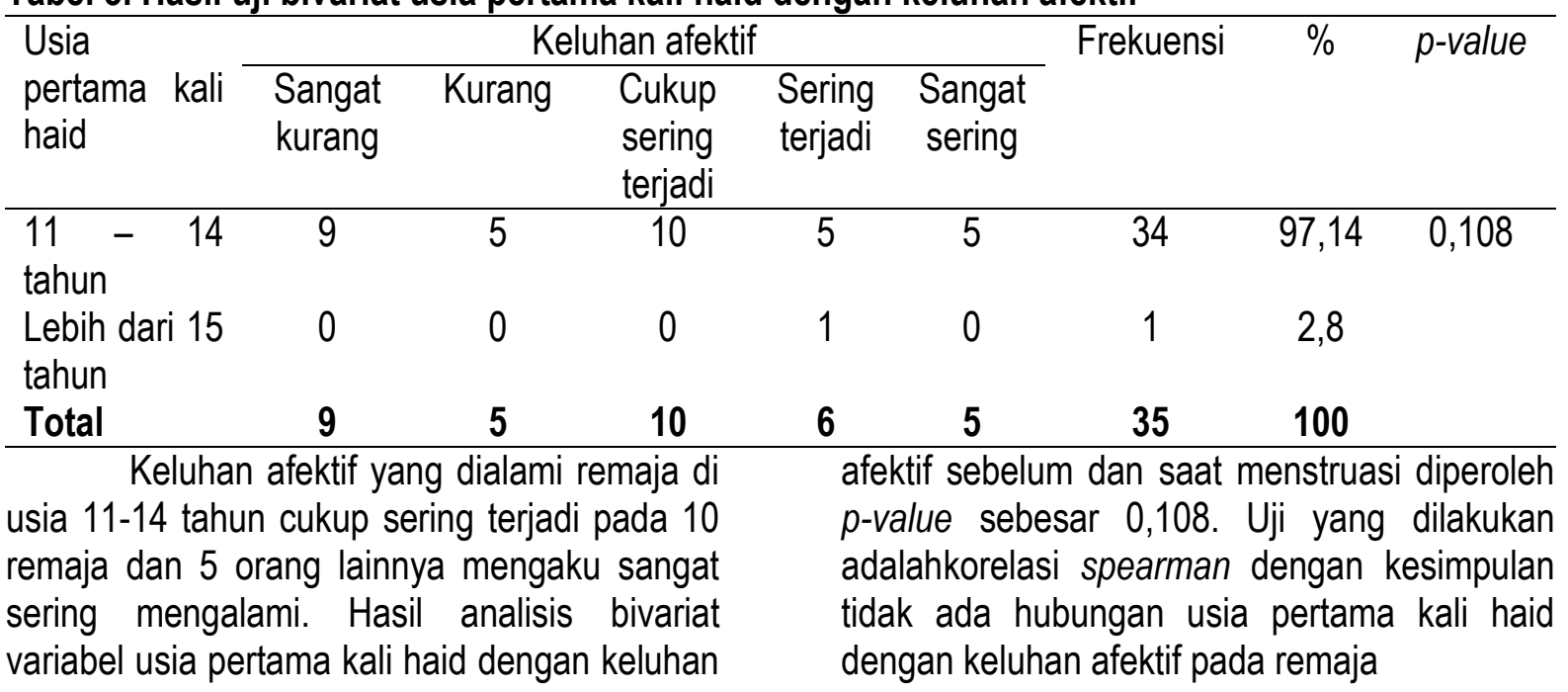

Tabel 4. Hasil uji bivariat kebiasaan sarapan dengan keluhan somatik

\begin{tabular}{|c|c|c|c|c|c|}
\hline \multirow[t]{2}{*}{ Kebiasaan sarapan } & \multicolumn{2}{|c|}{ Keluhan somatic } & \multirow[t]{2}{*}{ Frekuensi } & \multirow[t]{2}{*}{$\%$} & \multirow[t]{2}{*}{$p$-value } \\
\hline & $\begin{array}{c}\text { Tidak } \\
\text { mengalami }\end{array}$ & Mengalami & & & \\
\hline $\mathrm{Ya}$ & 5 & 19 & 24 & 68,57 & \multirow[t]{3}{*}{0,102} \\
\hline Kadang-kadang & 0 & 11 & 11 & 31,42 & \\
\hline Total & 5 & 30 & 35 & 100 & \\
\hline $\begin{array}{l}\text { Remaja yc } \\
\text { sarapan justru mer } \\
\text { somatic, hal ini terjad } \\
5 \text { lainnya tidak mer }\end{array}$ & $\begin{array}{l}\text { memiliki k€ } \\
\text { memiliki } \\
19 \text { respon } \\
\text { ni keluhan }\end{array}$ & & \multicolumn{3}{|c|}{$\begin{array}{l}\text { serta memiliki kebiasaan sarapan. Berdasarkan } \\
\text { tabel diketahui bahwa tidak ada hubungan } \\
\text { kebiasaan sarapan dengan keluhan somatik }\end{array}$} \\
\hline
\end{tabular}


selama masa menstruasi berlangsung pada

remaja dengan $p$-value sebesar 0,102 .

Tabel 5. Hasil uji bivariat kebiasaan sarapan dengan keluhan afektif

\begin{tabular}{|c|c|c|c|c|c|c|c|c|}
\hline \multirow{2}{*}{$\begin{array}{l}\text { Kebiasaan } \\
\text { sarapan }\end{array}$} & \multicolumn{5}{|c|}{ Keluhan afektif } & \multirow[t]{2}{*}{ Frekuensi } & \multirow[t]{2}{*}{$\%$} & \multirow[t]{2}{*}{$p$-value } \\
\hline & $\begin{array}{l}\text { Sangat } \\
\text { kurang }\end{array}$ & Kurang & $\begin{array}{l}\text { Cukup } \\
\text { sering } \\
\text { terjadi }\end{array}$ & $\begin{array}{l}\text { Sering } \\
\text { terjadi }\end{array}$ & $\begin{array}{c}\text { Sangat } \\
\text { sering }\end{array}$ & & & \\
\hline $\mathrm{Ya}$ & 7 & 2 & 7 & 5 & 3 & 24 & 68,57 & 0,000 \\
\hline $\begin{array}{l}\text { Kadang- } \\
\text { kadang }\end{array}$ & 2 & 3 & 3 & 1 & 2 & 11 & 31,42 & \\
\hline Total & 9 & 5 & 10 & 6 & 5 & 35 & 100 & \\
\hline $\begin{array}{r}\mathrm{Pa} \\
\text { dirasakan sal } \\
\text { lainnya me } \\
\text { yangguan afe }\end{array}$ & $\begin{array}{l}\text { abel } \\
\text { kurang } \\
\text { an cuk }\end{array}$ & $\begin{array}{l}\text { keluhan } \\
7 \text { rem } \\
\text { ering } m\end{array}$ & $\begin{array}{l}\text { afektif } \\
\text { tetapi } \\
\text { yalami }\end{array}$ & \multicolumn{5}{|c|}{$\begin{array}{l}\text { dengan keluhan afektif yang muncul saat pra } \\
\text { dan menstruasi berlangsung memberikan } \\
\text { informasi bahwa terdapat hubungan yang } \\
\text { positif dengan p-value sebesar } 0,000 \text {. }\end{array}$} \\
\hline
\end{tabular}

Hasil uji bivariat dengan uji korelasi spearman antara kebiasaan sarapan remaja

\section{PEMBAHASAN}

Periode menstruasi pertama kali yang terjadi pada masa pubertas seorang anak perempuan disebut sebagai menarche yang biasanya terjadi pada usia 10 hingga 16 tahun (Proverawati and Misaroh, 2009), pada hasil penelitian ini diperoleh bahwa rerata usia pertama kali haid pada siswi remaja SMA adalah 12 tahun dengan rentang usia 11-14 tahun merupakan rentang usia haid pertama kali paling banyak terjadi pada responden. Hal ini sejalan dengan hasil analisis data Riset Kesehatan Dasar pada tahun 2010 yang menunjukkan bahwa usia menarche pada remaja di Indonesia rata-rata mencapai usia 13 tahun (Riskesdas, 2013).

Umumnya siklus menstruasi akan terjadi setiap bulannya dengan siklus pada wanita normal adalah 28-35 hari dan lama haid antara 3-7 hari. Pada penelitian ini diperoleh informasi bahwa hampir seluruh responden mengalami lama haid 3-7 hari, dan Sebagian lainnya mengalami haid lebih dari 7 hari. Dikutip dari Wijayarini dkk(2005) terdapat fase ketidaknyamanan pada saat menstruasi yakni pada hari ke 1-2, karena terjadi perdarahan yang lebih banyak dan gumpalan darah lebih sering keluar. Berdasarkan pendekatan dengan wawancara mendalam, Sebagian responden mengakui mengalami ketidaknyamanan pada hari-hari tersebut dan mencoba menggali informasi dari peneliti apakah hal tersebut normal atau tidak. Hal ini membuktikan masih kurangnya informasi yang diperoleh remaja terkait dengan fase menstruasi.

Dalam penelitian ini usia pertama kali haid tidak memiliki hubungan dengan keluhan somatik yang timbul yakni abnormal uterine bleeding dan dysmenorrhea. Walaupun pada hasil univariat diperoleh data bahwa $74,3 \%$ remaja mengeluhkan pengalaman dysmenorrhea pada saat fase menstruasi berlangsung. Menstruasi yang dialami para remaja dapat menimbulkan masalah, salah satunya adalah nyeri haid atau dysmenorrhea. Dismenore merupakan masalah ginekologis yang paling umum dialami perempuan baik remaja maupun usia dewasa (Ningsih, Setyowati and Rahmah, 2013). Walaupun hasil penelitian sebelumnya dari Charu et al., (2012)menunjukkan bahwa perempuan dengan usia haid pertama kali kurang dari 12 tahun memiliki 23\% lebih tinggi kesempatan terjadinya dysmenorrhea dibandingkan dengan perempuan dengan usia pertama kali haid direntang usia 12-14 tahun. penelitian ini memaparkan bahwa remaja wanita yang mengalami usia haid dini mengalami paparan prostaglandin yang lebih lama dan berakibat pada kram dan nyeri pada perut.

Hasil penelitian menunjukkan tidak ada hubungan usia pertama kali haid dengan 
keluhan afektif. Hal tersebut juga dijelaskan oleh Sigmon et al (2012) bahwa sindroma premenstruasi merupakan kumpulan gejala fisik, psikologis dan emosi yang terkait dengan siklus menstruasi wanita, yakni gejala biasanya timbul 6-10 hari sebelum menstruasi dan menghilang ketika menstruasi dimulai.

Gejala yang paling parah dan paling sering pada sindroma premenstruasi adalah iritabilitas emosional dan tingkah laku, depresi, gelisah, kelelahan, konsentrasi berkurang, pembengkakan dan rasa tidak nyaman pada payudara dan nyeri di daerah perut.

Sigmon et al (2012) juga menjelaskan bahwa terdapat kurang lebih 200 gejala yang dihubungkan dengan PMS namun gejala yang paling sering ditemukan adalah iritabilitas (mudah tersinggung) dan disforia (perasaan sedih). Gejala mulai dirasakan 6-10 hari menjelang menstruasi berupa gejala fisik maupun psikis yang mengganggu aktivitas sehari-hari dan menghilang setelah menstruasi.

Lakhsmi (2011) menjelaskan fenomena fisiologis normal pada remaja wanita yaitu menstruasi, kualitas hidup seperti konsumsi makanan cepat saji, kurang aktivitas fisik dan melewatkan sarapan pagi dapat mempengaruhi gangguan menstruasi, tetapi dari hasil penelitian ini tidak terdapat hubungan kebiasaan sarapan dengan keluhan somatik remaja. Namun terdapat hubungan kebiasaan sarapan dengan munculnya keluhan afektif pada remaja sebelum dan saat menstruasi berlangsung, hal ini serupa dengan Richards and Gross (2000) yang menemukan fakta bahwa perilaku makan remaja memiliki hubungan yang signifikan dengan kejadian PMS. Perilaku makan dipengaruhi oleh beberapa faktor diantaranya adalah regulasi emosi.

Walaupun hasil penelitian
menunjukkan tidak adanya hubungan kebiasaan sarapan dengan munculnya keluhan somatik, tetapi gambaran hasil justru memberikan informasi bahwa 19 remaja yang mengalami keluhan somatik memiliki kebiasaan sarapan. Dalam bukunya yang berjudul Manajemen Kesehatan Menstruasi, Sinaga dkk(2017)menjelaskan bahwa pre menstrual syndrome dapat diatasi dengan makan makanan bergizi yakni makanan yang cukup mengandung protein, vitamin dan zat besi serta menghindari terlalu banyak asupan garam dan kafein yang terdapat dalam kopi, teh dan minuman berenergi lainnya. Dugaan sementara adalah remaja putri masih kurang dalam konsumsi buah dan sayuran, hal ini pun telah divalidasi melalui sesi wawancara pada 15 remaja yang terlibat.

Setengah dari keseluruhan remaja putri menyatakan bahwa menerima informasi Kesehatan reproduksi dari sekolah. Dalam laporan infodatin tahun 2015 diketahui bahwa partner diskusi tentang kesehatah reproduksi yang paling disukai remaja adalah termasuk salah satunya yakni guru, selain teman sebaya dan ibu. Artinya sekolah memiliki peran penting untuk memberikan tenaga pendidik yang menjadi salah satu sumber informasi valid permasalahan Kesehatan reproduksi remaja. Hal ini serupa pula dengan temuan utama SDKI Tahun 2017 dimana 59\% wanita memperoleh pelajaran tentang Kesehatan reproduksi manusia di sekolah. Informasi yang paling banyak diperoleh adalah pertumbuhan buah dada dan haid (BKKBN, 2017). 8 remaja menyatakan melihat informasi dari media visual, hal ini pun tercantum dalam laporan SDKI bahwa sumber informasi dari media visual diakses oleh $22 \%$ remaja putri. Disebutkan pula $79 \%$ remaja wanita memperoleh sumber informasi perubahan fisik masa pubertas dari guru. Penelitian ini menguatkan temuan bahwa guru dan sekolah memiliki peran penting dalam memaparkan informasi-informasi penting pada siswa/l khususnya masalah Kesehatan pribadi seperti masalah haid dan pubertas.

Dikutip dari Sinaga (2017) pada tahun 2015 Unicef melakukan penelitian di 16 sekolah yang terbagi pada 4 provinsi di Indonesia melaporkan bahwa Sebagian besar sekolah tidak menyediakan air yang cukup atau tempat tersendiri untuk praktik manajemen Kesehatan menstruasi. Hanya sedikit sekolah yang menyediakan tempat sampah untuk membuang pembalut di dalam toilet. Hasil penelitian ini melaporkan lebih dari setengah responden menyatakan sekolah menyediakan WC khusus dan disediakan air juga sabun 
pada fasilitas tersebut, walaupun masih ada beberapa lainnya yang melaporkan hal serupa yang ditemukan oleh Unicef di tahun 2015. Remaja dalam penelitian ini pun memberikan informasi bahwa tersedia pembuangan khusus untuk pembalut bekas pakai mereka, walaupun laporan Unicef menemukan hanya sedikit sekolah yang menyediakan tempat sampah untuk membuang pembalut. Menyediakan akses yang baik terkait menstruasi dan informasi bagaimana mengelola kebersihan selama menstruasi itu menjadi salah satu tantangan untuk mewujudkan personal hygiene menstruasi. Kurangnya informasi dan buruknya prasarana akan menyebabkan menstruasi pada remaja tidak terkelola dengan baik yang dapat menyebabkan munculnyakeluhan afektif dan somatik lain pada saat dan sebelum menstruasi berlangsung.

\section{KESIMPULAN DAN SARAN KESIMPULAN}

Berdasarkan hasil pengumpulan data pada remaja di SMA X Kota Samarinda diperoleh informasi bahwa tidak ada hubungan usia pertama kali haid dengan keluhan somatik, dan keluhan afektif, demikian juga kebiasaan sarapan dengan keluhan somatik. Tetapi ditemukan hubungan yang signifikan antara kebiasaan sarapan dengan keluhan afektif.

\section{SARAN}

Adapun saran yang dapat diberikan adalahperlu adanya penelitian komposisi sarapan remaja untuk menganalisis lebih lanjut hubungan sarapan dengan gangguan pramenstruasi; perlu adanya penggalian lebih dalam terkait lama haid, asupan nutrisi dan suplemen tambahan pada remaja selama masa haid berlangsung; remaja membutuhkan edukasi dalam mencegah dan menanggulangi keluhan yang muncul sebelum dan saat mentruasi berlangsung.

\section{UCAPAN TERIMAKASIH}

Tim peneliti mengucapkan terimakasih kepada Lurah Bukuan Kecamatan Palaran dan Bapak Ketua RT 23 yang memberikan kami kesempatan untuk melakukan penelitian diwilayah tersebut. Tak lupa kami haturkan apresiasi kepada seluruh remaja yang bersedia menjadi bagian dari penelitian ini

\section{DAFTAR PUSTAKA}

Abeje, A. and Berhanu, Z. (2019) 'Premenstrual syndrome and factors associated with it among secondary and preparatory school students in Debremarkos town, North-west Ethiopia, 2016', BMC Research Notes. BioMed Central, 12(1), pp. 1-5. doi: 10.1186/s13104-019-45499.

Abrani, A. A., Ningtyias, F. W. and Sulistiyani (2019) 'The Relationship between Food Consumption, Nutritional Status, and Physical Activity with Pre Menstrual Syndrome', Ghidza: Jurnal Gizi dan Kesehatan, 3(1), pp. 1-6.

Ahmed, S. B. and Saeed, A. A. (2019) 'Knowledge and Self - care Practices of Adolescent Students with Pre- menstrual Syndrome in Erbil City', Erbil Journal of Nursing and Midwifery, 2(1), pp. 9-18.

Antai, A. et al. (2010) 'Premenstrual syndrome: Prevalence in students of the University of Calabar, Nigeria', African Journal of Biomedical Research, 7(2), pp. 45-50. doi: 10.4314/ajbr.v7i2.54067.

BKKBN (2017) 'Survei Demografi Dan Kesehatan: Kesehatan Reproduksi Remaja 2017', Badan Kependudukan dan Keluarga Berencana Nasional, pp. 1-606. Available at: http://www.dhsprogram.com.

Charu, S. et al. (2012) "Menstrual characteristics" and "prevalence and effects of dysmenorrhea" on quality of life of medical students', International Journal of Collaborative Research on Internal Medicine and Public Health, 4(4), pp. 276-294.

Ernawati Sinaga, Nonon Saribanon, Suprihatin Nailus Sa'adah, Ummu Salamah, Yulia 
Andani Murti, Agusniar Trisnamiati, S. L. (2017) manajemen kesehatan menstruasi. Edited by GLOBAL ONE. jakarta.

Lakhsmi, et. al (2011) 'Prevalence of PreMenstruasion Syndrome and Dysmenorrhoea among Female Medical Students and Its Association with College Absenteeism: International Jurnal of Biological \& Medical Research', 2(4), pp. 1011-1016.

Maria A. Wijayarini, Peter I. Anugerah, Irene M. Bobak, Margaret Duncan Jensen, D. L. L. (2005) Buku Ajar Keperawatan Maternitas Edisi 4. 4th edn. jakarta: EGC.

Ningsih, R., Setyowati, S. and Rahmah, H. (2013) 'Efektivitas Paket Pereda Nyeri Pada Remaja Dengan Dismenore', Jurnal Keperawatan Indonesia, 16(2), pp. 67-76. doi: 10.7454/jki.v16i2.4.

Proverawati, A. and Misaroh, S. (2009) 'Menarche menstruasi pertama penuh makna'. doi: 10.1002/chem.201403489.

Puspitasari, R. L., Elfidasari, D. and Rahayu, K. M. (2014) 'Pengetahuan Mahasiswi Universitas Al Azhar Indonesia terhadap Premenstrual Syndrome', Jurnal AlAzhar Indonesia Seri Sains dan Teknologi, 2(3), pp. 193-198.

Renata, M. D. S., Widyastuti, N. and Nissa, C. (2018) 'Asupan mikronutrien sebagai faktor risiko kejadian sindrom pramenstruasi pada wanita vegetarian', Jurnal Gizi Indonesia, 6(2), p. 94. doi: 10.14710/jgi.6.2.94-101.

Richards, J. M. and Gross, J. J. (2000) 'Emotion regulation and memory: The cognitive costs of keeping one's cool', Journal of Personality and Social Psychology, pp. 410-424. doi: 10.1037/0022-3514.79.3.410.

Riskesdas (2013) 'Riset Kesehatan Dasar; Badan Penelitian dan Pengembangan
Kesehatan Kementerian Kesehatan RI Tahun2010', Laporan Nasional 2010, pp. 1-446. doi: 1 Desember 2013.

Sen, L. C. et al. (2018) 'Study on relationship between obesity and menstrual disorders', Asian Journal of Medical and Biological Research, 4(3), pp. 259-266. doi: 10.3329/ajmbr.v4i3.38464.

Shamnani, G. et al. (2018) 'Prevalence of premenstrual syndrome and premenstrual dysphoric disorder among medical students and its impact on their academic and social performance', National Journal of Physiology, Pharmacy and Pharmacology, 8, p. 1. doi:

10.5455/njppp.2018.8.0415728042018.

Sigmon, S. T. et al. (2012) 'Premenstrual Syndrome (PMS)', Encyclopedia of Human Behavior: Second Edition, 7(1), pp. 167-173. doi: 10.1016/B978-0-12375000-6.00288-3.

Takeda, T. et al. (2006) 'Prevalence of premenstrual syndrome and premenstrual dysphoric disorder in Japanese women', Archives of Women's Mental Health, 9(4), pp. 209-212. doi: 10.1007/s00737-006-0137-9.

Zaka, M. and Mahmood, K. T. (2012) 'Premenstrual syndrome- A review', Journal of Pharmaceutical Sciences and Research, 4(1), pp. 1684-1691. 